\title{
エレクトロニクス機器と自動車に対する 世界の環境規制
}

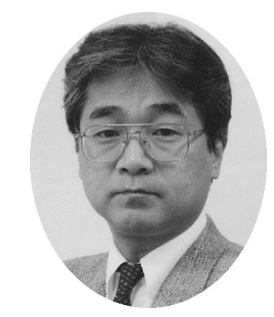

菅沼 克昭 *

Journal of Japan Institute of Light Metals, Vol. 57, No. 5 (2007), pp. 210-217

\section{World environmental legislations on electronics and vehicles}

\author{
Katsuaki SUGANUMA*
}

\begin{abstract}
Keywords: RoHS,J-MOSS, WEEE, ELV, environmental legislation
\end{abstract}
\section{1.はじめに}

環境調和技術は, エレクトロニクス機器産業, 自動車産業 にとり市場開拓のための一つのキーワードとして捉えられて きたが，21世紀に入り，世界的な有害物質使用に対する法規 制が先行する時代になり，一層の開発努力を迫る存在になっ た。言うまでもなく有害元素を多量に含んだ機器は廃棄りサ イクルを阻害し, 深刻な環境污染をもたらしている。日本は, 狭鄎な国土に毎年膨大な量のエレクトロニクス機器, 自動車 の廃棄問題を抱え, 製造者が意図せ女までも世界中へ廃棄物 を拡散し続けていることは事実である。同じ問題を抱える欧 州諸国では，いち早く有害物質の使用規制という他の地域で は類を見ない制度を築き，これがアジア諸国，日本，さらに は米国にまで広まりつつある。今や有害物質の工業製品から の削减は, 新たな市場開拓の必須の技術として捉えることが できる。

新たな有害物質使用規制を背景にする新技術開発の先端を 担ったのが，はんだの鉛フリー化であろう。これは，昨年の 7 月に始まった欧州連合の RoHS 指令によって義務付けられ た ${ }^{1)}$ 。RoHS 指令では, 鉛のほかに, カドミウム, 水銀, 六 価クロムと 2 種類の臭素系難燃材料屯使用規制対象になって いる。RoHS 指令は，エレクトロニクス機器製造の基盤技術 である接続材料を規制対象にし，技術的ハードルの高い鉛フ リーはんだ開発を余儀なくした法律として非常に大きなイン パクトをむたらした。まさに RoHS 指令は，立案当初に人が 予測できなかったサプライチェーンの一大変革をも引き起こ した。

欧州に端を発する一連の環境規制を表 1 にまとめた。本稿 ではRoHSだけに集中するが，すでに施行された WEEE指 令 ${ }^{1)}$ はもちろんであるが, REACH 規則, EuP 指令, Battery 指令を含めて総合的なエレクトロニクス，さらには ELV 指令 ${ }^{2)}$ の乗用車を含めた環境規制体制が整ったことに留意が必要で ある。
本稿では, 軽金属に対する視点と言うよりあ，むしろ新た な有害物質規制の世界的動向をご理解いただくために，まず 欧州指令の概要を述べ, その課題となっている現状に関して まとめよう。更に, 中国, 韓国, 更に米国における環境規制 の現状を簡単に紹介したい。以下に紹介する内容は 2006 年 末の情報であり, 制度として变更修正が適宜行われる情報で あり，常に新しい情報をアップデートしなければならない。 あらかじめこの点をご了解いただきたい。また, 日本の新た な制度 J-MOSS に関しては, 電子情報産業技術協会などの ホームページに詳細が掲載されているのでご参照いただきた い（J-MOSS:「電気・電子機器の特定の化学物質の含有表示 方法 (The marking of presence of the specific chemical substances for electrical and electronic equipment) 」, JIS C 0950) ${ }^{3)}$ 。

\section{2. 欧州の規制 (WEEE/RoHS)}

欧州連合 25 か国の共通の制度施策は，規則（regulation） や指令（directive）などのいくつかの段階で規定される。前 者はそれ自身が法律になるが，後者の指令は各国に持ち帰り 法律化されてはじめて拘束力を持つようになる。 RoHS 指令 は後者の性格になり, 基本的には各国で同等レベルの規制と なる。ちなみに, WEEE 指令は各国の裁量に任される部分が 多く, RoHS 指令とは性格が多少異なる。RoHS 指令を述べる 前に, これに先行して成立した自動車に対する ELV 指令 (Directive on End of Life Vehicles) を少し紹介しょう。ELV 指 令は成立が 2000 年で, RoHS 指令より 3 年早く成立している。 ELV 指令で 4 つの重金属の使用規制が決められ, RoHS 指令 に至る基本的な路線はこれによって形成されたと言える。た だし，鉛はんだは基板実装に用いる部分は除外されており， エレクトロニクス産業へ与えるインパクトはそれほど実感さ れなかった。ELV 指令の概要を表 2 にまとめたので参照して ほしい。

2003 年 2 月 13 日に, WEEE/RoHS 指令が正式成立した。 WEEE 指令が日本の家電リサイクル法に相当するものでリサ

*大阪大学産業科学研究所（干 567-0047 大阪府茨木市美穂ヶ丘 8-1）。 Institute of Scientific and Industrial Research, Osaka University (Mihogaoka 8-1, Ibaraki-shi, Osaka 567-0047).

受付日：平成 18 年 12 月 28 日 受理日：平成 19 年 2 月 21 日 
表 1 エレクトロニクス産業関連の国内外の環境規制

\begin{tabular}{|c|c|c|c|}
\hline 国 & & 法 & 成 立 年 \\
\hline \multirow{6}{*}{$\mathrm{EU}$} & WEEE 指令 & 電気製品廃棄処理のリサイクル・リユース規定 & \multirow{2}{*}{2003} \\
\hline & RoHS 指令 & 有害物質使用禁止 & \\
\hline & $\mathrm{EuP}$ 指令 & LCA を使いェコデザインの思想の製品造り & 2005 \\
\hline & REACH 規則 & 化学物質に対する規制 & 2006 \\
\hline & Battery 指令 & $\begin{array}{l}\text { バッテリの廃棄処理に関する規制 } \\
\text { 一部のカドミウム電池禁止 }\end{array}$ & $\begin{array}{l}1991 \\
2006\end{array}$ \\
\hline & ELV 指令 & 自動車の有害元素規制／廃車処理に関する規制 & 2000 \\
\hline \multirow{2}{*}{ 中国 } & 中国版 RoHS & 電気製品の有害物質使用禁止 & \multirow{2}{*}{2006} \\
\hline & 中国版 WEEE & 廃家電製品の処理等に関する規則 & \\
\hline 日本 & J-MOSS & 有害物質含有の情報開示義務 & 2005 \\
\hline 韓国 & 韓国版 RoHS & 電気製品・自動車の有害物質使用禁止・リサイクル規定 & 2007? \\
\hline 米国カリフォルニア州 & CA RoHS & 表示デバイスに関する有害物質規制 & 2006 \\
\hline
\end{tabular}

表 2 ELV 指令の概要

\begin{tabular}{|c|c|}
\hline 項目 & 規制内容 \\
\hline 環境負荷物質規制 & $\begin{array}{l}2003 \text { 年 } 7 \text { 月 } 1 \text { 日以降, 鉛, 水銀, カドミウム, 六価クロムの使用を禁止。適用除外 } 13 \text { 品目（附則 } \\
\text { II)。 }\end{array}$ \\
\hline \multirow[t]{2}{*}{ 処理規制 } & $\begin{array}{l}\text { 加盟国は ELV による污染を防止する処理を保証。処理施設は所管官庁の許可取得・登録を義務づ } \\
\text { け。 } \\
\text { バッテリ・液化ガスタンク取外し，エアバッグなど爆発の恐れのある部品取外し・無害化，各種 } \\
\text { 液体の除去，水銀含有部品の取外し }\end{array}$ \\
\hline & $\begin{array}{l}\text { リサイクル促進のための部品の取外し：触媒／ガラス, 銅/アルミニウム／マグネシウム含有部 } \\
\text { 品, バンパ／ダッシュボード／液体容器などの大物プラスチック部品・タイヤ（ただし，シュレッ } \\
\text { ダで回収できない場合） }\end{array}$ \\
\hline \multirow{2}{*}{$\begin{array}{l}\text { リサイクル率 } \\
\text { (実効率・可能率) }\end{array}$} & リサイクル可能率：95\% 以上（うち，エネルギー回収分 10\% 以内） \\
\hline & 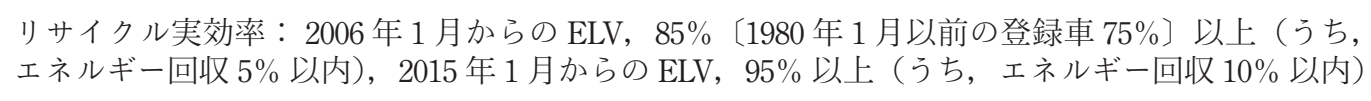 \\
\hline 回収ネットワーク & $\begin{array}{l}\text { ·加盟国は事業者が ELV および中古部品の回収・処理システムを確立することを保証。 } \\
\text { · } 2002 \text { 年 } 7 \text { 月 } 1 \text { 日以降の新車および } 2007 \text { 年 } 1 \text { 月 } 1 \text { 日以降の全 ELV が公認処理施設に確実に運ば } \\
\text { れること } \\
\text { •加盟国は解体証明書の提示を ELV の登録抹消条件とするシステム設立 }\end{array}$ \\
\hline 指令実行 & $\begin{array}{l}\text { • 加盟国は指令発効後，18 か月以内に本指令を遵守するのに必要な法律，規則，および行政規定 } \\
\text { を制定。 }\end{array}$ \\
\hline 無償引取り & $\begin{array}{l}\text { ·2002 年 } 7 \text { 月 } 1 \text { 日以降の新車および } 2007 \text { 年 } 1 \text { 月 } 1 \text { 日以降のすべての ELV を最終所有者の負担な } \\
\text { しに生産者が回収・処理。 }\end{array}$ \\
\hline
\end{tabular}

イクルやリユースなどを定義し，RoHS 指令が鉛などの重金 属と臭素系難燃材料の使用規制を定めている。WEEE/RoHS 指令の概要を表 3 にま之める。この指令の特徵的なことの一 つは, 有害物質の使用禁止を規定したことと, 生産者責任を
明言したことであった。後者は，製品のブランドを持つ者が， 無償で消費者から廃棄製品を回収し処理することを義務づけ るものである。

対象になるエレクトロニクス機器は, 車載用, 軍事用, 宇 
表 3 WEEE/RoHS 指令の概要

\begin{tabular}{|c|c|}
\hline 対象製品 & $\begin{array}{l}10 \text { ジャンル（民生・オフィス機器, RoHS 対象: ゴシックの } 8 \text { ジャンル) } \\
\text { 大型家電, 小型家電, IT ・ 通信機器, 一般民生機器, 照明, 電動工具, 玩具・レ } \\
\text { ジャ一機器, 医療機器, モニ夕機器, 自動販売機 }\end{array}$ \\
\hline $\begin{array}{l}\text { 再生率／再利用率 } \\
\text { (2006 年 } 12 \text { 月 } 31 \text { 日までに） }\end{array}$ & 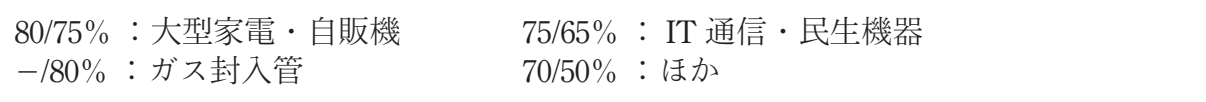 \\
\hline $\begin{array}{l}\text { 廃棄前処理システム確立の義務化 } \\
(2005 \text { 年 } 8 \text { 月 } 13 \text { 日から })\end{array}$ & $\begin{array}{l}\text { すべての液体と特定有害元素を含む部品はすべて事前に除去 } \\
\text { (PCB や水銀部品, バッテリ, 携帯電話基板, 一般基板 }>10 \mathrm{~cm}^{2}, \text { トナー, 臭素系難 } \\
\text { 燃材, アスベスト部品, ブラウン管, } \mathrm{CFC} / \mathrm{HFC} / \mathrm{HCFC} / \mathrm{HC}, \text { ガス封入管, 液晶 }>100 \mathrm{~cm}^{2} \text {, } \\
\left.\text { 外部電線, セラミック繊維部品, 放射性物質部品, 電解コン> }>25 \mathrm{~mm}^{t} \times \phi 25 \mathrm{~mm}\right)\end{array}$ \\
\hline $\begin{array}{l}\text { 有害化学物質使用規制 } \\
\text { (2006 年 } 7 \text { 月 } 1 \text { 日か ら) }\end{array}$ & $\begin{array}{l}\text { 鉛, 水銀, カドミウム, } 6 \text { 価クロム, } \mathrm{PBB} / \mathrm{PBDE} \\
\text { 限界值：鉛, 水銀, } 6 \text { 価クロム, } \mathrm{PBB} / \mathrm{PBDE} \quad 1000 \mathrm{ppm} \\
\text { カドミウム } \\
2006 \text { 年 } 7 \text { 月 } 1 \text { 日以前に販売開始された製品の再使用やスペア部品には適用除外。今後 } \\
\text { の技術の進歩によって代替が可能になるものは医療・モニタ機器む含め適用除外から } \\
\text { 外す (2005 年 } 2 \text { 月 } 13 \text { 日以前に再検討, 次回は } 2010 \text { 年)。 }\end{array}$ \\
\hline
\end{tabular}

表 4 RoHS 指令の除外項目（2006 年 12 月の時点）

水 銀

水銀量が $5 \mathrm{mg}$ 以下の小型蛍光灯, 一般用途の蛍光直管（上限值：ハロゲン系りん酸物質が $10 \mathrm{mg}$, 通常の耐久性で三基りん酸 物質が $5 \mathrm{mg}$ ，長期耐久性で三基りん酸物質が $8 \mathrm{mg}$ )，特定目的で使用される直線状蛍光管，当該付属書で定義されない蛍光管

鈆

はんだ関係 [高融点はんだ (鉛量 $85 \%$ 以上)，2 種類以上の成分からなる $80 \sim 85 \%$ 鉛量の MPU，フリップチップ用半導体ダイ 接続，サーバ・記憶装置・記憶装置アレイシステムの鉛はんだ，電気通信基幹系ネットワーク（切替，信号，送信のための ネットワークインフラのはんだ中の鉛)，コンプライアント・ピンコネクタ，熱伝導 $\mathrm{c}$-リングのめっき，0.65 mm 以下のファイ ンピッチリードめっき（コネクタは除く），ラウド・スピーカ変換器, machined through hole discoidal and planar array セラミック コンデンサ $],$ ブラウン管・蛍光管・電子部品・光学用途のガラス，合金元素 $[$ 鉄鋼中 $0.35 \%$, アルミニウム中 $0.4 \%$, 銅合金 中 $4 \mathrm{mass} \%$ ，鉛入り青銅製シェルと軸受け，電子セラミック部品中の鉛 [例えば，圧電デバイス，，光通信の RIG ファラデー 回転子の不純物, PDP/SED の構造用途鉛酸化物 (誘電体, 電極, シールなど), 特殊用途 BLB のガラス, LCD の平面蛍光灯の鉛 ガラスシール，小型省エネランプのアマルガム $(\mathrm{PgBiSn}-\mathrm{Hg})$, 特殊蛍光体 $\left(\mathrm{BaSi}_{2} \mathrm{O}_{5}: \mathrm{Pb}\right.$ など）の活性剂鉛，プロ用高輝度ラン プのハライド鉛 (複写機)，シリケートコート白熱ランプの鉛，クリスタルガラスの鉛，ほう酸ガラス用エナメル中の鉛

カドミウム

76/769/EEC を改正した指令 91/338/EEC で制限外のカドミウム接点および表面処理，ほうけい酸ガラスのエナメルに使うイン ク, 光学用途のガラス

六価クロム

吸収型冷蔵庫の炭素鋼冷却システムの防錆めっき，基幹系通信機器の防食・防磁めっき（2007年 7 月 1 日まで）

その他

デカ $\mathrm{BDE}$

宙用を除いたほとんどの電機・電子製品が含まれている。 RoHS 指令は，モ二夕機器や医療機器を除外した部分に科せ られている。民生品ばかりでなく多くの工業用機器も含まれ る。機器の名称で市場に混乱も生じているが, 基本的には表 4 の除外項目に明記されない限り有害物質を基準值以下に抑 えるべきと捉えたい。規制対象の元素には，鉛，カドミウム， 水銀, 六価クロムのほかに, ダイオキシン発生が懸念される 2 種類の臭素系難燃材料 (PBB/PBDE) が含まれている。許
容值は表のとおりである。これらの濃度は「均質な部分で」 測定することを必要とし, 製品のケーブルや箱体などの大き なボリュームのあるパーツは検査可能としても, 実装基板に 載った部品のめっきやはんだは簡易な測定を行う通関での検 査は不可能である。実質上の検査基準が国際標準 IEC などで 検討が続いている。規制された難燃材料は，日本ではあまり 一般的ではないとされるが, 今後, 技術的な進展や環境負荷 の状況を判断して規制される難燃材料の範疇は拡大される。 
表に記したように，それぞれの物質に関してはいくつかの技 術的に代替が難しい除外項目が設けられる。例えば，鉛に関 しては，鉛酸化物を含む電子部品や 85 mass $\% \mathrm{~Pb}$ 以上の高温 はんだが除外され，サーバなどの情報系基幹インフラも除外 されている。微細接続技術の代表的なもののフリップチップ 接続は, 当面は法規制の対象外にされた。2006 年末の時点 で，除外製品は更に拡大しつつあり，制度そのものがまだ完 全に落ち着いたものではない。直近の報告では, 医療機器と モニ夕機器に対する規制は, 新技術の信頼性が確認されてか らが望ましいと指摘され, 早くて 2012 年頃からではないかと 予測される。除外に関する企業や各国政府関係者のロビー活 動は極めて盛んで, まさに世界中の利害関係者を巻き込んだ 動きになっている。

さて, WEEE 指令に規定されるリサイクル/リュース率は, 日本の家電リサイクル法よりもかなり厳しい。回収の実績を 確認するために，2006 年 12 月 31 日までに住民あたり平均 4 $\mathrm{kg}$ を回収することが決められていたが, 各国の制度確立が遅 れたことから達成できない国も少なからずあったと思われる。 リサイクル条項に関しては 2008 年 12 月 31 日までに検討をふ まえた上で, 数字が更新される。廃棄処理の義務も厳しく設 定されている。有害元素や物質は用いないことが原則である が, 万一代替不可能で用いることを余儀なくされる場合であ, 廃棄処理段階の除去が必要になる。鉛はその除去対象に含ま れ，例えば規制対象除外の高鉛はんだを用いた場合，ある一 定の基準值を上回ればすべて除去を義務づけられる。

\section{3. 中国版 RoHS「電子情報製品污染防止管理法」の 概要}

2006 年 2 月末に中国版 RoHS と略称される「電子情報製品 污染防止管理法」(中国語名称：电子信息产品污染控制管 理办法（信息产业部第 39 号令)）が正式発布された ${ }^{4)}$ 。2003 年初頭に, 突然のように中国において RoHS 検討が始まった ことが知らされ世界を驚かせたが, 約 3 年を経ての正式決定 に至ったものである。当初は，「国土が広く廃棄物の問題な ぞないはずの中国がなぜ?」と疑問にも感じられたが，実際 に大都市周辺での廃棄物による環境污染の進行や，地方都市 においては国外から不法に持ち込まれる電子機器の解体作業 が引き起こす污染などが大きな問題となり, 中国当局も真剣 に環境保全を考え前向きな対策が必要とされていた。言うま であなく今日の中国の経済成長は驚異的でさえあり，これに よって特に大都市周辺では人口過密と同時に大量の廃充物の 問題が急速に浮上してきている。先手を打って廃棄物問題に 対応しないとこの先手遅れになりかねず, 真剣に廃棄物の無 害化，リサイクルの容易化を画策しているわけである。

中国の場合の RoHS は, 欧州指令とは異なり直接的に取り 締まる法律になる。中国版 RoHS は突然に現れたものではな い。図 1 は, 中国における一連の環境規制の相関を示してい る。中国版 RoHS は，これ以前に制定された 2 つの法律「グ リーン生産促進法 (中国語名称: 清洁生产促进法)」, 「固体 廃棄物污染環境防止法（中国語名称：固体废物污染环境防 治法)」と深く関連している。もちろん，欧州の RoHS 指令に 大きく触発されたものであることは間違いがない。

欧州の WEEE 指令や日本の家電リサイクル法, PC リサイ クル法に相当する中国版 WEEE「廃家電及び電子製品リサイ

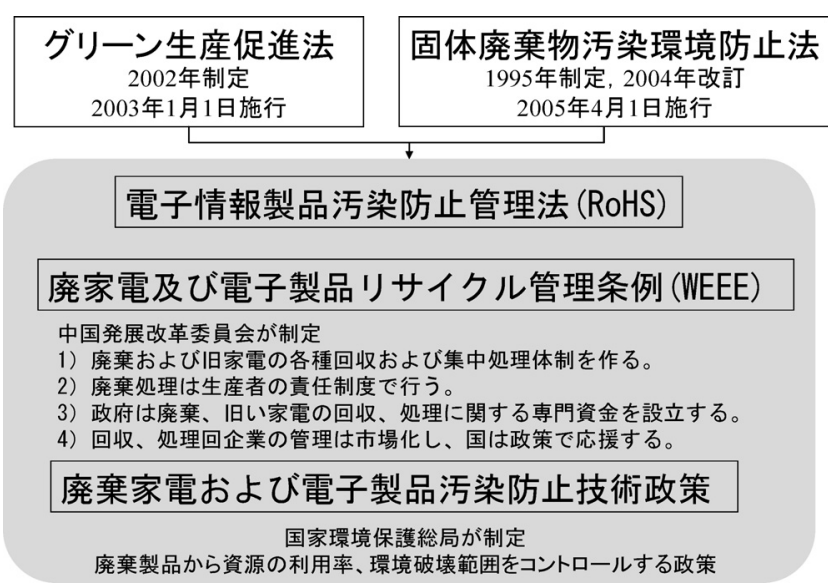

図 1 中国の電子機器に関する環境規制関連

クル管理条例（中国語名称：废旧家电及电子产品回收处理 管理条例)」屯準備されている。中国版 RoHS は「管理法」と 呼ばれ, 日本で言うと省令に当たり, 中国版 WEEE は「条 例」と呼ばれ, 国務院が制定する法律となる。すなわち, 中 国版 WEEE は国家発展改革委員会が制定に務め, 廃棄およ び旧家電の回収抢よび集中処理体制, 生産者の情報開示義務 や廃棄処理責任制度, 政府の廃家電製品の回収処理システム 確立義務などが盛り込まれる。

中国版 RoHS とWEEE に加えて, さらに, 環境保護総局が 準備する「廃家電及び電子情報製品の污染防止技術政策」 (中国語名称：废弃家用电器与电子产品污染防治技术政策, 略称として“WEEP”とも呼ばれる）も準備されているが, これは, 家電製品の設計や廃棄製品から資源の利用率, 環境 破壊範囲をコントロールする政策である。「政策」は，あく までも産業界の指導の意味合いであり，法的な規制ではない。 技術政策の対象になるのは, 家電製品としてテレビ, 冷蔵 庫, エアコン, 洗濯機, 掃除機など, 電子情報製品としてコ ンピュータ, プリンタ, ファックス, コピー機, 電話機など が含まれる。このWEEP の三つの原則として，（1）製品の環 境配慮設計によるごみ減量化，（2）再使用・リサイクルによ る省資源化,（3）廃棄電子製品中の有害物質削除に重点を置 き,さらに, この制度の特徴として製品のサプライチェーン の上流にも及ぶ責任制度の導入がある。この責任制度では, 具体的にはサプライチェーン中の各企業は自らの責任で自社 部品・製品をチェックし, 製品の環境影響を最小化するため に努力しなければならない。

わかりやすいように中国版 RoHS と欧州 RoHS 指令の主な 差異の比較を表 5 に示したので, 参考にしてほしい。法律の 施行は 2007 年 3 月 1 日が予定されているが，この日時は有害 物質の使用規制開始とは異なる可能性がある。この規制開始 はまず製品への各種情報を明記したラベル添付から始まり, 次に規制対象製品が鉛フリー化されていれば 3 C 認定 (China Compulsory Certification : 中国強制製品認証制度，20 種類, 135 品目, 3 C マークがないと輸出入, 販売が禁止される) へ と移る。実際の有害物質規制開始日は, 後述の重点管理目録 が公表されることが必要で，これから決定される。

使用が規制される対象元素は，欧州 RoHS と同じく，鉛， 水銀, カドミウム, 六価クロムの 4 種類の重金属と, 2 種類 の臭素系難燃材料であるが, さらに, その他の国家指定有害 
表 5 中国版 RoHS と欧州 RoHS 指令の主な相違点

\begin{tabular}{|c|c|c|}
\hline & 相 違 点 & 共 通 点 \\
\hline 中国版 RoHS & $\begin{array}{l}\text { 1. 下位の法律規範性文書に転換する必要なく, } \\
\text { そのまま実施する。 } \\
\text { 2. 対象は電子情報製品であるが，適用拡大可能性は } \\
\text { 大。 } \\
\text { 3. 有害物質の制御，監督を管理するのは「目録」の } \\
\text { 管理を採用し，目録は窮挙法を用いて形成する。 } \\
\text { 4. } 2006 \text { 年 } 2 \text { 月 } 28 \text { 日に発布し，2007 年 } 3 \text { 月 } 1 \text { 日施行。 } \\
\text { 有毒有害物質の制限，禁止は? } \\
\text { 5. 規制には, 「標準」と「重点管理目録」の制定が } \\
\text { 必要である。 } \\
\text { 6. 上市企業は製品の第 } 1 \text { 段として有害元素情報・安全 } \\
\text { 情報を開示し，その後に } 3 \text { 認定を受け「管理」する。 }\end{array}$ & \multirow[t]{2}{*}{$\begin{array}{l}\text { 1. 両者とあ法律規制文書である。 } \\
\text { 2. 主な目的は有毒有害物質を制御する（禁止 } \\
\text { する, 減量化する)。 } \\
\text { 3. 貿易活動にかかわる } \\
\text { 4. 制限, 禁止する有毒有害物質は：鉛，水銀, } \\
\text { カドミウム, 六価クロム, 多臭素化ビフェニル } \\
\text { （PBB), 多臭素化ジフェニルェーテル (PBDE)。 } \\
\text { (中国は対象元素が増える可能性を含む) }\end{array}$} \\
\hline 欧州 RoHS & $\begin{array}{l}\text { 1. 指令はじかに拘束力がない, 欧州連合構成メンバー } \\
\text { 国の法律 (法規) に転換してから実施できる。 } \\
\text { 2. 対象は, 交流電圧では } 1000 \text { ボルト, 直流電圧では } \\
\text { 1500ボルトを超えない, すべての電子, 電気設備。 } \\
\text { 3. 有毒有害物質の制御は, 技術的にまだ未成熟, } \\
\text { 経済的に不可能なとき,「除外」を用いて免除を与える。 } \\
\text { 4. } 2003 \text { 年 } 2 \text { 月 } 13 \text { 日に指令発行し, } 2004 \text { 年 } 8 \text { 月 } 13 \text { 日に } \\
\text { 欧州連合メンバー国が法律転換し, } 2006 \text { 年 } 7 \text { 月 } 1 \text { 日 } \\
\text { から有害物質使用禁止。 } \\
\text { 5. 「指令」の遂行は「標準」の整備が必要である。 } \\
\text { 6. 上市企業は, 自己宣言のみ。 }\end{array}$ & \\
\hline
\end{tabular}

元素が含まれている。国家指定有害元素とは, 今後, 中国独 自の基準で規制元素を増やす可能性を残したものといえる。 上記物質の許容濃度も含めて, 現時点ではまだ決定されてい ない。

規制の対象製品は,

電子情報製品, 電子情報技術で生産した電子レーダ, 電子 通信製品, ラジオ・テレビ製品, コンピュータ, 家庭用電 子製品, 電子測定計器製品, 電子専用製品, 電子部品, 電 子応用製品, 電子材料などの製品および部品

となり，これらのアクセサリや梱包なども含まれる。海外輸 出は対象外となるが，一方で中国への輸入製品にはすべて掛 かる。この点は, 欧州 RoHS 指令も同様である。欧州指令と 大きく異なる点は，規制対象の製品をリストに造り上げる方 式としたことであろう。このリストは，「重点管理目録」と 呼ばれ，この目録に収録された製品のみ $3 \mathrm{C}$ 認定を行い規制 対象になる。このように欧州 RoHS 指令のような除外項目に よる有害元素の使用規制ではなく，重点管理目録による規制 製品の積み上げ方式を採用した背景には，欧州 RoHS 指令の 調査において欧州市場が混乱するようすを判断して採用した あのと言われる。目録の積み上げ方として, 製品の部分的な 登録むあり得るとされる。たとえば，冷蔵庫が鉛フリー化に おいて複数枚の基板のうちの一部の基板が鉛フリー化された 場合，鉛フリー化された基板部分のみが目録へ組み入れられ る。このように, 制度適用の柔軟性も考えている。しかし, 目録をゼロから積み上げる方式は, 膨大な種類の機器の存在 を考えると，気の遠くなるような手法とも感じられる。

中国版 RoHS では, 欧州 RoHS 指令では除外されている車 載機器や大型 FA 機器をいずれ含む可能性がある。重点管理
目録は, 市場の状況や技術発展を見て適宜見直しが行われる が, 欧州のように 4 年ごとという決まりはなく, 頻繁に実施 されるむのと考えられる。これには政府の 7 組織が担当する ことになるが, 関与する組織が多いことはかなりの混乱を招 くのではないかと懸念される。

生産者責任も明確に定義されている。生産者は, 製品の環 境調和性を実現する設計, 生産過程で研究設計の方案を变 更, 工程プロセスを調整, 使用材料を代替, 製造方法を革新 するなどの技術措置を行い, 使用する有毒, 有害物質の名称 および含有量を製品に表記, かつ電子情報製品の環境安全使 用期限を明示するなどの措置が要求される。また, 技術的に 先行するメーカが評価されることが明言されている。サプラ イチェーンにおいて流通ルートを厳格に管理し, 電子情報製 品中の有毒, 有害物質を管理する国家標準あるいは業界標準 に達していない電子情報製品の販売や輸入を遮断することが 必要となる。電子情報製品の上に安全使用期限を明記するこ とが, 義務づけられる。少々わかりづらい言葉であるが，「安 全使用期限」とは製品の使用において有害物質が溶け出て害 毒を及ぼさない期限の意味である。また, 電子情報製品の上 に有毒有害物質の名称, 含有量, 部品回収 ·再利用の可否な どを明記しなければならない。製品のサイズなどの制限で表 示が困難な場合は，仕様書などへの表示で代替できる。

電子情報製品の RoHS 適合の判断のために, 国内の標準や IEC/TC111 国際標準に準拠した国家標準を元に検定マニュア ルを確定することになる。また，国内の関連する標準として，

『電子情報製品に含まれる有害物質の含有量基準』 


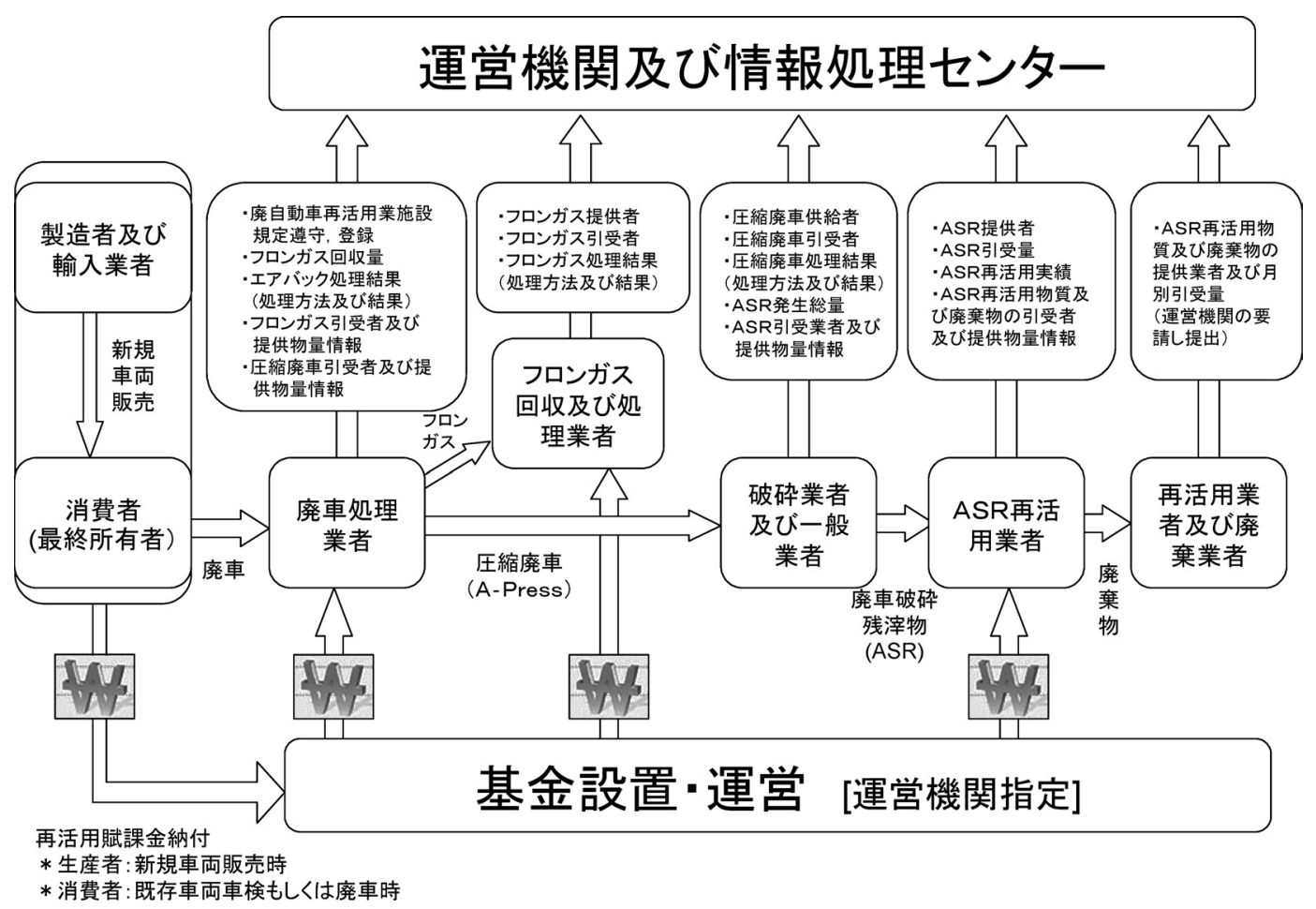

図 2 韓国 RoHS の自動車廃棄時の管理系統

『鉛フリーはんだの化学成分』

『鉛フリーはんだの材料標準』

などが運用される。これら基準により，たとえばはんだ中の 鉛量が規定される。まだ正式決定には至っていないが，鉛に 関しては, 当初から欧州 RoHS 指令と同じレベルの $0.1 \mathrm{mass} \%$ が採用されるであろう。

欧州 RoHS 指令と異なるあう一つのことに，製品包装に国 家標準・業界標準に基づく無毒・易分解素材を用い, 素材名 称の明記を義務づけることがある。この場合も大きさなどの 制限から表示できない場合は, 説明書などへの表示が義務づ けられる。欧州指令では，製品の包装に関しては指令の範囲 外之なっている。生産者は, 廃旧電子情報製品の回収処理費 用を負担し，国定企業に回収・リサイクル・処理を依頼す る。

違反者に対する罰則は, 生産者, 販売者, 輸入者が対象と なり，この点は欧州 RoHS 指令之同様である。制度の運用は, 地方自治体（県，自治区，直轄市など）が実際の管理を行う ことになるが，本システムにおいて顕著な業績を挙げたもの は表彰される反面, 担当官の職権乱用は法的に厳しく罰する ことが条文の中に明言されている。

\section{4. 韓国と米国の RoHS 関連規制の状況}

韓国では，欧州 WEEE/RoHS 規制と ELV 規制の動向を踏ま えて, 2005 年末に「電子機器電気・電子製品及び自動車の資 源リサイクルに関する法律立法予告」を公表した ${ }^{5)}$ 。立案を 担当する部局は，環境省になる。以下の情報に関しては 2006 年 11 月初旬の次点でまだ案のままであり, 今後の変更があ る可能性もあることには，ご留意いただきたい。

韓国版 RoHS 案の法構成は, 図 2 のようになっている。全 6 章 47 条で構成され, 第 1 章が総則であり,この法案の目的 とするところ, 語句の定義, 製造者や国民の義務, 地方自治
体の義務，委員会の規定などが述べられている。第 2 章は, 電気・電子製品等の材質・構造改善などに関するものであ り，有害物質使用規制と（自動車に関する）リサイクル率, 分析評価方法の公示, 情報公開責務, さらに, 製品の使用者 やリサイクル業者の安全性確保に関して規定される。第 3 章 では, 廃電気・電子製品及び廃自動車のリサイクルの詳細に 関して述べられている。第 4 章では, 自動車リサイクル促進 基金に関して, 第 5 章は補則, 第 6 章が罰則, さらに付則に 施行日などが規定されている。また, 本法案に関連する法律 として,「廃棄物管理法」と「資源の節約とリサイクル促進 に関する法律」打よび「自動車管理法」などが存在する。

法律施行時期は, 2007 年 7 月と付則に規定されている。欧 州 RoHS からちょうど 1 年後を設定している。規制の対象元 素や濃度は, 法案には具体的には示されず, 対象製品は環境 省の省令で決められ，現在のところ規制の対象となる製品は， 環境省から別に配付された資料に以下のように記述されてい る。

·電子製品 : テレビ, エアコン, 洗濯機, 冷蔵庫, オー ディオ, 携帯電話, プリンタ,コピー機, ファックス

·自動車：乗用車, 3.5 トン以下の乗合自動車, トラック

また, 法案中では, 具体的な定義は触れられておらず, 電 気・電子機器は「電流や電磁気場によって作動する機械・機 構（その製品に使われる部品を含む）」，自動車に関しては $\lceil 「$ 自動車管理法」第 2 条第 1 号の規定による自動車（その製 品に使われる部品を含む)」とのみの表現になっている。ま た，上記の文言に認められるように，いずれも生産者責任を 基本とする規制になる。

有害物質の対象となる元素は, 欧州 RoHS と同じく, 鉛, 水銀, 六価クロム, カドミウムの 4 種類の重金属と, 2 種類 
の臭素系難燃材料が含まれる。また，欧州と同じく除外規定 を取る方式を採用し，許容量基準も同等になり，カドミウム が $0.01 \%$ になるほかは $0.1 \%$ が基準になる。

リサイクルに関しては, 設計製造段階での事前管理と廃棄 時の事後管理にわけて定義されている。事前管理では, 生産 者の義務として, 有害物質の含有情報, リサイクル容易性確 保および情報提供が義務化され, 特に, 省令に従ってリサイ クル業者に対してリサイクル以前に処理しなければならない 有害物質, 解体情報, 製品を構成する物質, 部品組成などの 情報を提供しなければならない。

廃棄時の管理としては, 生産者および輸入業者がリサイク ル目標達成の義務を負うことになる（両者を合せてリサイク ル義務者と言う)。電気・電子機器のリサイクル目標率, 自 動車のリサイクル目標率を表 6 にそれぞれ示す。リサイクル 義務者は, あらかじめ製品のリサイクル目標義務を達成する ための計画を環境省に提出し，その承認を得る必要がある。 ただし, リサイクル業務を受け持つ電気・電子製品リサイク ル事業共済組合が設立されるので, ここに分担金を納めたも のはこの限りではない。この場合も達成率の報告は必要であ り,「リサイクル義務履行結果報告書」の提出が必要になる。 万一，リサイクルを達成できない事業者は，リサイクルで必 要となる費用の $3 / 10$ 以下の “電気・電子製品リサイクル賦課 金”を環境省へ納める必要がある。買い換えの際の新製品の 購入に拈いては, 消費者からの回収処理を無償で履行する。

自動車のリサイクルに関しては, “自動車リサイクル賦課 金”を生産者・輸入業者か自動車の持ち主が負担する。自動 車の場合は, 廃自動車リサイクル業者がリサイクル達成など の報告義務を負う。図 2 には, 現在考えられている自動車の リサイクルに関する管理系統案の説明を示すのでご参照いた だきたい。

検査に関しては, 必要に応じて関係公務員が現場立ち入り の検査を行えることを規定している。リサイクル責任者は帳 簿等の規定された資料の記録保管を義務付けられるが，リサ イクルなどに関する情報処理センターが設置されるので，そ こへ報告を行うことでこれに替えることができる。環境省は, 試験分析機関を指定することができるが，基本的に分析手法 は国際標準に従うと思われる。罰則も細かに規定されている。

\section{5. 米国の RoHS 規制}

米国では，連邦全体の環境に対する取り組みは，環境省で ある EPA（Environmental Protection Agency）が司っている。 米国連邦法におけるエレクトロニクス機器に関する物質規制 は，特に鉛の使用に関して 1990 年代の初頭に検討が開始さ れ, 結局 1993 年に電気・電子機器を規制対象から除外する ことで終わっている。したがって, 当面は連邦法としてのエ レクトロニクス機器に対する有害物質規制は提案されにくい 状況にある。

一方で，米国では連邦法のほかに各州の定める州法がある。 現在, 各州は増加する電気・電子機器に対する監視を強化し つつあり, “eCycling”のキャンペーン名の下に廃棄物減量対 策が進められている。特に，テレビやパソコンのモニタの回 収が推奨されており，何らかの連邦法としての規制も検討さ れつつある。州により環境に対する規制の姿勢は大きく異な り, 電気・電子機器の廃棄に対する個別の州法も見られる。
表 6 （a）韓国 RoHS に規定された，電気・電子製品のリ サイクル目標率（再使用および物質再活用の基準）

\begin{tabular}{l|c|c}
\hline \hline & 2005 年 & 2006 年以降 \\
\hline テレビ, パソコン & $55 \%$ & $65 \%$ \\
携帯電話 & $60 \%$ & $70 \%$ \\
冷蔵庫, オーディオ & $60 \%$ & $70 \%$ \\
洗濯機, エアコン & $70 \%$ & $80 \%$ \\
\hline
\end{tabular}

表 6（b）韓国 RoHS に規定された，自動車一台あたりの リサイクル目標率

\begin{tabular}{c|c|c}
\hline \hline 再活用方法 & $\begin{array}{c}2006.1 .1 \\
\sim 2015.1 .1\end{array}$ & 2015.1 .1 以後 \\
\hline \begin{tabular}{c} 
再使用および物質再活用可能率 \\
\hline $\begin{array}{c}\text { 再使用, 物質再活用および } \\
\text { エネルギー回収可能率 }\end{array}$
\end{tabular} & $80 \%$ 以上 & $85 \%$ 以上 \\
\hline
\end{tabular}

これらは総称して “Universal Waste”として管理方法などが 定められている。モ二夕に対する廃棄・回収などに関する規 定が，すでにニューハンプシャー州などの 4 つの州で決めら れている。また, 電気・電子機器回収などがコロラド州など 2 州で, さらに，水銀を含む多くの機器に対する規定が，コ ロラド州をはじめとする8つの州で制定されている。

一方で，環境保全に対してもっと屯先進的な取り組みをし ているのがカリフォルニア州である。この州では, Proposition65 (Safe Drinking Water and Toxic Enforcement Act of 1986）という法律が 1986 年に制定され, 有害元素による水 源への污染の監視を強めて来た。この法律は水質管理が主た る対象であるが，頻繁に改正や規制強化が行われており，そ の情報は webに登録することで自動的に配信される。カリ フォルニア州では, エレクトロニクス機器のリサイクルに関 する法律が 2003，2004 年に “Electronic Waste Recycling Act of 2003 (SB20, SB50)” として提案認可され, 主にディスプレイ などの回収リサイクルが義務化された。これが，やはり欧州 の RoHS の影響を受け，米国版の初の RoHS となって昨年の 成立に至った。

カリフォルニア版 RoHS では対象となる機器が限定され, “Covered Electronics Device（CED）”のみになる ${ }^{6)}$ ○このカテ ゴリは, 9 種類のモニ夕製品が含まれるが, 基本的にテレビ やモニタなどの 4 インチ以上の表示機器のみになる。有害元 素として規制されるものは，鉛，水銀，六価クロム，カドミ ウムのみで, 難燃材料に関する条項はない。最大許容值は, 欧州 RoHS に準じるとされている。技術的に代替できない製 品に関しては, 除外項目あ欧州指令にならって認めるようで ある。ただ，法律の施行後む有害物質を許容以上に含む製品 の販売が規制されるものではない。施行日は, 2007 年 1 月で ある。生産者は, 毎年カリフォルニア州の定める機関 (CIWMB: California Integrated Waste Management Board) への 用いた有害元素の種類と量などを報告する義務が課せられる。 PBB に関しては，規制はないが報告の義務は生じる。このよ うに，現状のカリフォルニア州の規制は，限られた製品の限 られた元素, また販売の禁止はないなどの緩やかな規制であ 
ると言える。ただ，欧州規制に基本的に準じるもので，更に 2010 年ごろを目指し規制を拡大する議論むなされていると聞 くので，今後の推移に注目をしたい。

\section{RoHS による有害物質使用規制の今後}

本稿では，2006 年に開始した欧州 RoHS 指令に基づく有害 物質使用規制, 2007 年から開始されるであらう中国, 韓国と 米国の RoHS 規制関連の動向に関して紹介した。欧州におい ては, 連合 25 か国で統一された RoHS 基準が適用されるはず であったが，すでに動き出した現時点においてあ国ごとにわ ずかな差異があり, 生産者・輸入業者に少なからず混乱を招 いている。一方で, 欧州 RoHS は日本を含む世界中へ着実に 波及しつつあり，その様態は地域により大きな差異を持つよ うになっている。対象製品に差があるばかりでなく, 拘束力 などにも大きな差を有する。たとえば，日本における J-MOSS は 7 製品に限定され，JIS 化はされているあのの罰則等は定め られておらず，拘束力はない緩やかなものである。米国カリ フォルニアの RoHS では更に緩く限定された範囲になってい る。一方, 欧州連合はもち万んであるが, 中国や韓国のよう に厳しい罰則規定を設け，環境規制に強制力を持たせる国々 あある。中国や韓国は規制が適用される製品範囲はまだある 程度限られているが，今後臨機応変に拡大する方針であるの で, 日米とは規制拡大, 拘束力に扔いて少々方針が異なるも のになる。差異の大きい規制が各国で設けられることは, 生 産のグローバル化を推進する国内企業, あるいは多くの海外 企業にとっても対応に苦慮しなければならない状況になった と言える。世界的になったと同時に, このような地域の個性
を持つ有害物質使用規制に無難に対処するためには，各国の 制度をよく理解することはむちろんであるが, あっとも先進 的な規制制度を敷く欧州の RoHS，さらにはこれに関係する， WEEE 指令, ELV 指令, EuP 指令, REACH 規則, Battery 指 令を十分に理解することが望まれる。物造りが難しい時代に なったと言えるが，一方でこれらの環境規制を切り抜けるこ とができる企業が生き残る新しい時代に入ったことをしっか りと認識する必要があるだろう。

\section{参考文献}

1）欧州 RoHS 指令：Directive on the restriction of the use of certain hazardous substances in electrical and electronic equipment, Official Journal of the European Union, 13.2.2003, L 37/19

欧州 WEEE指令： Directive on waste electrical and electronic equipment (WEEE), Official Journal of the European Union, 13.2. 2003, L 37/24

2) 欧州 ELV 指令 : Directive on end-of life vehicles, Official Journal of the European Communities 21.10.2000, L 269/34.

3) J-MOSS : 日本工業規格「電気・電子機器の特定の化学物質の 含有表示方法 (The marking for presence of the specific chemical substances for electrical and electronic equipment) 」, JIS C 0950, http://home.jeita.or.jp/eps/jmoss.html

4）中国版 RoHS : http://www.mii.gov.cn/art/2006/03/02/art_524_ 7343.html（中国商務部英語訳 http://english.mofcom.gov.cn/aarticle/policyrelease/domesticpolicy/200605/20060502132549.html)

5）韓国版 RoHS : http://www.me.go.kr/dev/legislation/legislation view.jsp?key $=\&$ search $=\&$ from $=\&$ to $=\& m s b h=\&$ title $=\& n o=20060$ $001 \& p g=5$

6) 米国カリフォルニアRoHS：http://www.dtsc.ca.gov/ HazardousWaste/EWaste/upload/Restriction_on_Electronic_Devices_ 01-05-06.pdf 